\title{
ПАРТИТИВНІ ІМЕННИКОВІ ТРИКОМПОЗИТИ У СЕРЕДНЬОВЕРХНЬОНІМЕЦЬКІЙ ТА СУЧАСНІЙ НІМЕЦЬКІЙ МОВІ
}

Статтю присвячено порівняльному аналізу семантичних особливостей партитивних іменникових трикомпозитів у середньоверхньонімецькій та сучасній німецькій мові. Дослідження базується на корпусі складних трикомпонентних іменників, дібраних методом суцільної вибірки із тлумачних словників середньоверхньонімецької (57 лексичних одиниць) та сучасної німецької мови (318 лексичних одиниць). Категорію партитивності розглянуто у роботі на словотвірному рівні через призму іменникових трикомпозитів. У процесі дослідження визначено семантичні групи партитивних трикомпонентних іменників на основі семантичних ролей їхніх безпосередніх складників та формул тлумачення, створених відповідно до семантичних відношень між безпосередніми складниками. В результаті проведеного аналізу встановлено, що найчисельнішою семантичною групою партитивних іменникових трикомпозитів в обох порівнювальних періодах є семантична група «ціле частина».

Ключові слова: іменниковий трикомпозит, партитивність, семантичний тип, семантична група, семантичний відмінок, формула тлумачення.

\section{Е. В. БЕЛЕЦКАЯ. ПАРТИТИВНЫЕ СУБСТАНТИВНЫЕ ТРИКОМПОЗИТЫ В СРЕДНЕВЕРХНЕНЕМЕЦКОМ И СОВРЕМЕННОМ НЕМЕЦКОМ ЯЗЫКЕ}

Статья посвящена сопоставительному анализу семантических особенностей партитивных субстантивных трикомпозитов в средневерхненемецком и современном немецком языках. Исследование основывается на корпусе сложных трехкомпонентных имен существительных, полученном методом сплошной выборки из толковых словарей средневерхненемецкого (57 лексических единиц) и современного немецкого (318 лексических единиц) языка. Категория партитивности рассматривается в работа на словообразовательном уровне через призму субстантивных трикомпозитов. В процессе исследования выделено семантические группы партитивных трехкомпонентных имен существительных на основе семантических ролей их непосредственных составляющих и формул толкования, созданных в соответствии с семантическими отношениями между непосредственными составляющими. В результате проведенного анализа установлено, что наибольшей по количественным показателям семантической группой партитвных субстантивных трикомпозитов, которая зафиксирована в двух сравниваемых периодах, является семантическая группа «целое - часть».

Ключевые слова: субстантивный трикомпозит, партитивность, семантический тип, семантическая группа, семантический падеж, формула толкования.

У сучасному мовознавстві одне з центральних місць займають дослідження у сфері словотвірної семантики. Актуальність семантичних досліджень пояснюється не лише порівняно недавньою історією вивчення цього питання, але й складністю самого об'єкта дослідження. адже словотвірна семантика, базується на співвідношенні семантики похідного і твірного слова і виражається за допомогою певних словотворчих 
засобів (Циганенко, 1983). Не зважаючи на те, що словотвірна семантика має відносно недавню історію дослідження - iï розквіт припадає на другу половину минулого століття - сучасна лінгвістична наука накопичила великий досвід у вивченні цього питання. Так, особливостям словотвірної семантики окремих словотвірних моделей на матеріалі німецької мови присвячені роботи І. Барц, Р.П.Бота, В. С. Вашуніна, Н. Г. Іщенко, О. С. Кубрякової, В. Куршнера, Дж. Н. Леві, В. Мотча, Г. Й. Нойхауса, М. Рікхайта, М. Д. Степанової, Й. Томана, І. С. Улуханова, В. Фляйшера та ін. Однак, спеціалізація семантичних розвідок на певному обмеженому матеріалі не дозволяє охопити всі пласти лексики в межах одного дослідження, що зумовлює наявність ділянок, які потребують більш детального вивчення та аналізу. Саме до таких ділянок відносяться складні слова у німецькій мові. Методика дослідження словотвірної семантики складних слів вперше була розроблена в Інституті німецької мови у м. Іннсбрук (Австрія) в рамах проекту “Словотвір німецької мови : Типи та тенденції сучасної німецької мови” під керівництвом Й. Ербена і висвітлена у колективній монографії “Іменникові трикомпозити” (Ортнер, 1991). Із незначними відмінностями ця методика застосована для аналізу складних слів усередньоверхньонімецькій мові, результати якого представлені у колективній монографії “Граматика середньоверхньонімецької мови. Словотвір" (Кляйн, 2009). Ця методика побудована на основі теорії відмінкової граматики. Це означає, що на першому етапі визначаються семантичні відмінки (ролі) безпосередніх складників композитів та встановлюються семантичні відношення між ними. На наступному етапі на основі семантичних ролей детермінативу та основного слова та семантичних відношень між ними вибудовуються формули тлумачення (словотвірні парафрази), які дозволяють виділити основні 31 семантичний тип композитів, найчисельнішими 3 яких $\epsilon$ акціональні (18,2\%), референційні (13,3 \%) та партитивні (11,6 \%) складні слова (Ортнер 1991: 145).

Партитивність, тобто співвідношення понять «частина» і «ціле», розглядається в лінгвістиці як субкатегорія посесивності - однієї з універсальних понятійних категорій мови, основне значення якої полягає у визначенні назви об'єкта через його відношення до певної особи або предмету (Ярцева 1990 : 389). Отже, партитивні відношення є одними з універсальних семантичних відношень, що притаманні багатьом мовам світу. Проблема співвідношення частини і цілого на різних рівнях мови розглядається у низці лінгвістичних розвідок українських та зарубіжних лінгвістів (I. О. Бодуен де Куртене, О. В. Бондарко, Г. С. Дедюхіна, О. Ссперсен, Н. Б. Іваницька, 
В. В. Ільїн, К. Леманн, О. В. Материнська, О. О. Реформатський, Г. В. Ситар, Б. А. Успенский, Д. Цефферер, Р. Якобсон та ін.). Однак, не зважаючи на доволі суттєву кількість робіт, присвячених вивченню категорії партитивності, поза увагою лінгвістів все ще залишаються певні лакуни, які потребують подальшого детального дослідження. Саме до таких лакун належать іменникові трикомпозити, у складі яких реалізуються відношення партонімії.

Отже, об’єктом пропонованого дослідження виступають складні трикомпонентні іменникові у середньоверхньонімецькій та сучасній німецькій мові.

Предметом дослідження $є$ іменникові трикомпозити, в яких реалізуються відношення партонімії.

Мета роботи полягає у проведенні порівняльного аналізу семантичних груп партитивних іменникових трикомпозитів у середньоверхньонімецькій та сучасній німецькій мові.

Для досягнення поставленої у роботі мети вирішуються такі завдання:

- провести кількісні спостереження над розподілом партитивних іменникових трикомпозитів у загальному складі іменникових трикомпозитів у середньоверхньонімецькій та сучасній німецькій мові;

- визначити семантичні ролі безпосередніх складників у складі трикомпонентних іменників зазначеного семантичного типу;

- встановити формули тлумачення на основі семантичних ролей детермінативу та основного слова та семантичних відношень між ними;

- розподіли партитивні іменникові трикомпозити на семантичні групи відповідно до семантичних ролей безпосередніх складників та формул тлумачення;

- провести порівняльний аналіз семантичних груп партитивних іменникових трикомпозитів у зазначені періоди розвитку німецької мови.

Новизна роботи полягає в тому, що у дослідженні вперше розглянуто категорію партитивності на матеріалі іменникових трикомпозитів у німецькій мові та проведено порівняльний аналіз семантичних груп партитивних іменникових трикомпозитів на основі семантичних ролей їхніх безпосередніх складників у різні періоди розвитку німецької мови.

Актуальність дослідження зумовлена збільшенням наукового інтересу до основних понятійних категорій мови, а також відсутністю лінгвістичних розвідок, 
присвячених вивченню однієї з цих категорії - категорії партитвності - на матеріалі іменникових трикомпозитів у середньоверхньонімецькій та сучасній німецькій мові.

Емпіричний матеріал дослідження складають іменникові трикомпозити, отримані шляхом суцільного добору, із словників середньоверхньонімецької М. Лексера та Г. Ф. Бенеке, В. Мюллера, Ф. Царнке - 357 одиниць, та сучасної німецької мови Дуден - 2992 одиниці.

Іменникові трикомпозити у середньоверхньонімецькій мові представлені 10 , а у сучасній німецькій мові - 22 семантичними типами, що свідчить про розширення семантичної палітри, на позначення якої слугують іменникові трикомпозити у німецькій мові (Білецька 2013: 17).

Партитивні іменникові трикомпозити, які називають величину за відношенням їі приналежності до величини вищого рівня, при цьому за кількісними показниками посідають перше місце у середньоверхньонімецькій мові та друге місце, після акціональних іменникових трикомпозитів, у сучасній німецькій мові. Їхня кількість становлять 57 одиниць, 16 \% та 318 одиниць, 10,6 \% відповідно (Білецька, 2013).

Відповідно до семантичних ролей, які виконують безпосередні складники у складі трикомпонентних іменників, партитивні іменникові трикомпозити у німецькій мові можна поділити на декілька семантичних груп:

1. Семантична група «ціле - частина»

Детермінатив (А-конституент) іменникових трикомпозитів цієї семантичної групи виконує семантичну роль цілого, а основне слово (В-конституент) підпорядковане йому і позначає відокремлювану або невідокремлювану частину цього цілого. Формула тлумачення трикомпозитів пропонованої семантичної групи виглядає так «В $€$ частиною А», напр.:

1.1. Семантична підгрупа «ціле - відокремлювана частина»

підпорядкування

свн. ërtber-blat stf. $\rightarrow$ das Blatt ist ein (abgesonderter) Teil der Erdbeere;

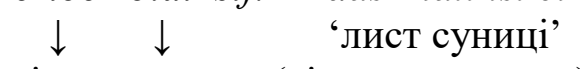

ціле - частина (відокремлювана)

підпорядкування

HBH. das Lorbeer-blatt $\rightarrow$ das Blatt ist ein (abgesonderter) Teil des Lorbeers

$\downarrow$
$\downarrow$
ціле - чластина (відокремлювана) 
1.2. Семантична підгрупа «ціле - (невідокремлювана) частина»

підпорядкування

свн. hentschuoch-gürtel swm. $\rightarrow$ der Gürtel ist ein (integrierter) Teil des Handschuhs

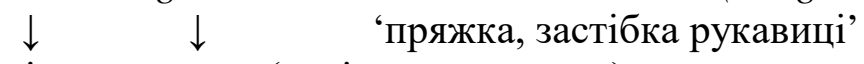

підпорядкування

HBH. der Fahrrad-lenker $\rightarrow$ die Lenkstange ist ein (integrierter) Teil des Fahrrads

$$
\begin{gathered}
\downarrow \\
\downarrow \\
\text { ціле - частина (невідокремлювана) }
\end{gathered}
$$

2. Семантична група «група (колектив) - елемент»

Детермінатив (А-конституент) іменникових трикомпозитів цієї семантичної групи виконує семантичну роль колективу або групи предметів (осіб), об'єднаних спільною метою (спільним завданням), а основне слово (В-конституент) підпорядковане йому і позначає елемент (члена) цієї групи (цього колективу). Цій семантичній групі відповідає формула тлумачення «В належить / відноситься до / є членом А», напр.:

підпорядкування

свн. kirchspil-man swm. $\rightarrow$ der Mann ist der Mitglied des Kirchspiels

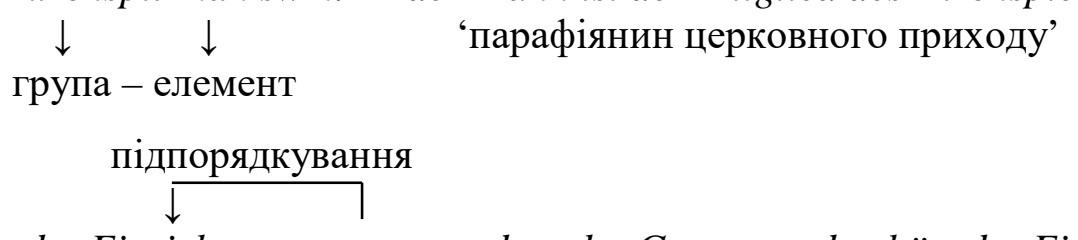

HBH. der Einrichtungs-gegenstand $\rightarrow$ der Gegenstand gehört der Einrichtung

$$
\text { група - елемент }
$$

3. Семантична група «носій - ознака / якість»

Детермінатив (А-конституент) іменникових трикомпозитів цієї семантичної групи виконує семантичну роль носія певної ознаки (якості), яка виражена підпорядкованим основним словом (В-конституентом) і $є$ типовою / характерною для цього носія. Формула тлумачення цієї семантичної групи має такий вигляд «В є типовим / характерним для А», напр.:

$$
\text { підпорядкування }
$$

нвн. Besteuerungs-grundlage $\rightarrow$ die Grundlage, die typisch für die Besteuerung ist

$$
\begin{array}{cc}
\downarrow & \downarrow \\
\text { носій - ознака }
\end{array}
$$


4. Семантична група «величина походження - частина (відокремлена, оброблена)»

Детермінатив (А-конституент) іменникових трикомпозитів цієї семантичної групи виконує семантичну роль величини походження, а підпорядковане йому основне слово (В-конституент) виражає відокремлену від нього і піддану певній обробці частину. Формула тлумачення іменникових трикомпозитів цієї семантичної групи виглядає «В походить від / з А», напр.:

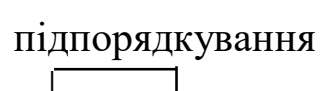

HBH. Haifisch-leder $\rightarrow$ das Leder, das von einem Haifisch stammt

$\downarrow \quad \downarrow \quad$ 'оброблена шкіра акули'

величина - частина

походження (відокремлена, оброблена)

Підводячи підсумки проведеного аналізу, можна зробити такі узагальнюючі висновки:

- партитивні відношення, що є одними з провідних семантичних відношень, характерних для більшості мов світу, знаходять свою реалізацію і на проміжному словотвірному рівні мови, що свідчить про універсальність однієї 3 основних понятійних категорій мови - категорії партитивності;

- за кількісними показниками партитивні іменникові трикомпозити займають перше місце у середньоверхньонімецькій та посідають друге місце у сучасній німецькій мові, після акціональних іменникових трикомпозитів. Це дає змогу стверджувати, що партитивні відношення $\epsilon$ найхарактернішим типом семантичних відношень, за якими будуються трикомпозити у німецькій мові;

- визначені семантичні ролі безпосередніх складників у складі іменникових трикомпозитів, а також встановлені на основі семантичних відношень між ними формули тлумачення уможливили виділення у рамках партитивних трикомпонентних іменників чотирьох семантичних групи: «ціле - частина», «група (колектив) елемент», «носій - ознака / якість», «величина походження - частина (відокремлена, оброблена)»;

- не всі виділені семантичні групи партитивних іменникових трикомпозитів знайшли свою реалізацію в обох порівнювальних періодах розвитку німецької мови. Так, останні дві семантичні групи «носій - ознака / якість» та «величина походження частина (відокремлена, оброблена)» репрезентовані лише у сучасній німецькій мові; 
- семантична група «ціле - частина» є найчисельнішою в обох порівнювальних періодах i представлена двома семантичними підгрупами в залежності від відокремлюваності / невідокремлюваності частини від цілого.

Перспективним можна вважати дослідження категорії партитивності на матеріалі складних слів інших структурних типів та в інші періоди розвитку німецької мови, а також проведення порівняльного аналізу особливостей партитивних композитів у різних мовах.

\section{СПИСОК ЛІТЕРАТУРИ}

1. Білецька O.В. Іменникові трикомпозити в середньоверхньонімецькій і сучасній німецькій мовах : автореф. дис. на здобуття наукового ступеня канд. філол. наук : 10.02.04 «Германські мови» / О. В. Білецька. - Донецьк., 2013. - 21 с.

2. Циганенко Г. П. Словотвірне значення як категорія дериватології / Г.П. Циганенко // Словотвірна семантика східнослов'янських мов. - К. : Наукова думка, 1983. - С. 5-17.

3. Языкознание. Большой энииклопедический словарь / Гл. ред. В. Н. Ярцева. - 2-е изд. М. : Большая Российская энциклопедия, 1998. - 685 с.

4. Benecke G.F., Müller W., Zarncke F. Mittelhochdeutsches Wörterbuch [Електронний pecypc]. - Режим доступу до словника : http://urts55.uni-trier.de:8080/Projekte/MWV/wbb

5. Duden. Das große Wörterbuch der deutschen Sprache : In $10 \mathrm{Bd}-\mathrm{n}$. [Електронний ресурc]. - PC-Bibliothek Version 2.01 mit Plus-Paket / Hrsg. und bearb. vom Wissenschaftlichen Rat u. d. Dudenred., Projektleitung und Projektmanagement der CD-ROM ISBN : 3-411-71001-2 Volker Kling. - Mannheim ; Wien ; Zürich : Bibliographisches Institut, 2000. - Систем. вимоги : P-100, Windows 9X/ME 32MBRam ; Windows / NT / 2000. - 64 MBRam ; SVGA, CD-ROM. - Назва 3 титул. екрана.

6. Klein Th. Mittelhochdeutsche Grammatik. Teil III. Wortbildung / Thomas Klein, HansJoachim Solms, Klaus-Peter Wegera. - Tübingen : Niemeyer, 2009. - 684 S.

7. Kürschner $W$. Zur syntaktischen Beschreibung deutscher Nominalkomposita. Auf der Grundlage generativer Transformationsgrammatiken / Wilfried Kürschner. - Tübingen : Niemeyer, 1974 . -228 S.

8. Lexer M. Mittelhochdeutsches Wörterbuch / M. Lexer. - Stuttgart: S. Hirzel Verlag, 1992. 1. Band. A - M. - 2262 S.

9. Lexer M. Mittelhochdeutsches Wörterbuch / M. Lexer. - Stuttgart: S. Hirzel Verlag, 1992. 2. Band. N - U. - $2050 \mathrm{~S}$.

10.Lexer M. Mittelhochdeutsches Wörterbuch / M. Lexer. - Stuttgart: S. Hirzel Verlag, 1992. 3. Band. V, F - Z, Nachträge. - 1632 S.

11.Ortner L. Substantivkomposita (Komposita und kompositionsähnliche Strukturen 1) // Deutsche Wortbildung : Typen und Tendenzen der deutschen Gegenwartssprache ; eine Bestandsaufnahme des Instituts für Deutsche Sprache, Forschungsstelle Innsbruck. Vierter Hauptteil Sprache der Gegenwart, Bd. LXXIX / Lorelies Ortner, Elgin Müller-Bollhagen. - Berlin ; New York : de Gruyter, 1991. - 863 S. 